\title{
The Relationship between IPO Price and Liquidity: Empirical Evidences from Iran
}

\author{
Leila Bateni ${ }^{1}$, Fraydoon Rahnama Roodposhti ${ }^{1}$, Zahra Poorzamani ${ }^{2}$ \& Farshid Asghari ${ }^{3}$ \\ ${ }^{1}$ Economics \& Management Department, Science and Research Branch, Islamic Azad University, Tehran, Iran \\ ${ }^{2}$ Department of Accounting, Central Tehran Branch, Islamic Azad University, Tehran, Iran \\ ${ }^{3}$ School of Economics, Payame-Noor University, Tehran, Iran \\ Correspondence: Leila Bateni, Economics \& Management Department, Islamic Azad University, Science and \\ Research Branch, Hesarak, Tehran, I. R. Iran. Tel: 98-919-355-8656 or 147-789-3855. E-mail: \\ batenileila@gmail.com
}

Received: March 8, 2014

Accepted: April 22, 2014

Online Published: May 25, 2014

doi:10.5539/ijef.v6n6p226

URL: http://dx.doi.org/10.5539/ijef.v6n6p226

\begin{abstract}
The underpricing of initial public offerings (IPOs) is generally explained with asymmetric information and risk. We complement these traditional explanations with a new theory where investors worry also about the after-market illiquidity that may result from asymmetric information after the IPO. The less liquid the aftermarket is expected to be, and the less predictable its liquidity, the larger will be the IPO underpricing. Our model blends such liquidity concerns with signaling theory. The model's predictions are supported by evidence for 36 IPOs from Tehran Stock Exchange between 2006 and 2012. Using Hui \& Heubel ratio of liquidity, we find that after-market liquidity is an important determinant of IPO pricing. Practical implementation-the finding of the study could be helpful for university students and users of financial information and other financial analysts in capital market.
\end{abstract}

Keywords: initial public offering (IPO), after-market liquidity, capital market

\section{Introduction}

Widely offering of securities to the investors is called "Initial Public Offering" \& the first general offering of securities by a firms called "Initial Public Offering (IPO)". Public offering of securities has a lot of advantages for the disseminators as follows:

i. Gaining capital for the growth \& development of activity.

ii. Gaining useful information via expert analyzers.

iii. Increasing the company's performance.

iv. The suppliers of financial sources \& investors will trust more.

The underpricing of the shares sold through initial public offerings (IPOs) is generally explained in the literature with asymmetric information about the security's value and with its fundamental risk. For the IPO to attract sufficient interest, the issuer must leave enough "money on the table" to compensate investors for the uncertainty about the security's value. However, until now the literature has largely disregarded how after-market liquidity may impact on the IPO underpricing. Maybe this study is the first one in Iran that tests the relationship between secondary-market liquidity and (IPO) pricing. This is a striking omission in view of the established evidence that the returns of securities include a liquidity premium. One would expect such premium to be paid also by stocks in the process of being floated. Moreover, at the IPO stage, investors do not know precisely how liquid the aftermarket will be. This suggests that they will not only care about expected liquidity but also about the uncertainty about it, that is, about liquidity risk. Our article fills this gap. It complements traditional explanations with theory and evidence showing that after-market liquidity is an important determinant of IPO underpricing. We provide a model showing that an IPO that is expected to be more illiquid and to have higher liquidity risk should feature higher underpricing.

The amount of private information that remains undisclosed after the IPO depends partly on how much information is released at the IPO stage, which is in turn related to the type of IPO mechanism used. Busaba and 
Chang (2002) show that the bookbuilding process elicits much information from informed traders at the IPO stage by promising larger allocation of valuable stocks to investors who truthfully reveal their information and therefore reduces the impact that such informed traders have in the after-market trading. In contrast, the fixed-price method, that does not elicit such private information at the IPO stage, enables informed traders to use such information in the aftermarket at the expense of the uninformed. The comparatively high adverse selection problems associated with the fixed-price method will spill over from the IPO stage to the aftermarket. This in turn means that liquidity will be relatively more important for IPOs carried out through a fixed-price method than through bookbuilding. This suggests that the empirical analysis must control for the IPO mechanism. Our model nests the predictions about the effects of after-market liquidity on IPO underpricing with those of traditional models. We test for the presence of these liquidity effects on IPO underpricing, controlling for the variables suggested by other theories of IPOs. Our sample includes all the companies that went public on the Tehran Stock Exchange between September 2006 and March 2012.

In line with our model and previous microstructure studies, we focus on measures of liquidity variables that are related to Transaction Volumes in the trading process: the Hui \& Heubel Ratio proposed by Hui \& Heubel. (1984) Consistent with our hypothesis, we find that IPO underpricing is higher for shares featuring lower expected liquidity and higher liquidity risk. The effects of liquidity variables are found to be robust to the IPO Underpricing and After-Market Liquidity inclusion of the other factors traditionally used to explain IPO underpricing, that is, variables capturing asymmetric information such as underwriter reputation, fundamental risk (such as age of firm, firm size).

To gain perspective, it is useful to set our contribution against the background of the literature. Many models explain IPO underpricing with some form of information asymmetry about the true value of the IPO shares. In Rock (1986), the information asymmetry is among potential IPO investors: some are "informed" and others "uninformed," generating a winners' curse problem. The informational asymmetry may also induce investors to rely on other buyers' behavior in placing their bids, leading to an informational cascade. This happens in Welch (1992), where issuers underprice IPO shares to attract some potential investors in the IPO, whose bids will in turn attract other investors. The study which was performed by Lofran et al. has approved the phenomenon of short-term yield or in other words, low-pricing the Initial Public Offerings of the share in 25 developed or under-development countries. Researchers presented various reasons for low-pricing. These reasons had been formed and presented in the shape of traditional theories such as Information Asymmetry or new theories such as behavioral theories. The most prominent of these theories are as follows: a theory based on Information Asymmetry which illustrates different levels of information between various groups, a theory based on control considerations and ownership structure, theories based on institutional reasons and behavioral and financial theories (Admati \& Pfleiderer, 2009).

About the issue of abnormal short-term yield, in his study, Rock (1986) points out to two investor groups in the market: informed investor and non-informed investor. The result of this study showed that the average of the yield of share purchaser investors in their Initial Public Offering was more than the normal yield of the market. Baron (1989) has used the theory of corporative governance in illustrating the abnormal short-term yield as the consequence of Information Asymmetry between disseminator companies and investment banks. He came to this conclusion that low-pricing, as much as representative charges for the presented information, is imposed to the firm by investment companies. Other studies such as Mascarla and Vetsuypens (1989), examined Baron's theory. The results of their studies didn't approve Baron's hypothesis. In 1989, Mascarla and Vetsuypens studied 74 companies and examined Information Asymmetry between Disseminator Firm and investors. They realized that low-pricing in the second public offering is less than the initial one. The result of their study was disseminated under the name of "Signaling Hypothesis". In this theory, there is an Information Asymmetry between the firm which offers share and potential investors in the market. Various hypothesizes were presented in the field of informing (signaling), such as the Effect of Insiders and Market Feedback Hypothesis.

Lilan and Pile (1977) used the proportion of internal investors as a signaling parameter to evaluate the expected cash of the company. Based on this theory, the more the number of internal investors, the performance of the firm is better and therefore, this is a signal for a good share. In this model, there is a positive relationship between the low-pricing of Initial Public Offering share and the internal value of the company. Welsch (1989) says that the firm which disseminates shares has more information in the field of its own value, so the more the mentioned firm is valuable, the more it uses low-pricing valuing as a signal to the market. Green Blot and Hwang (1989) believe that the internal value of the firm has a direct relationship with the low-pricing of Initial Public Offering share of that company. Chemaner (1993) cited that low-pricing, covers the charges of collecting information in the market. The more the prices of information gathering, the more low-pricing will be. Amihod 
and Mandelson investigated the effect of liquidity in pricing properties (Hui \& Huebel, 1984). They analyzed the relationship between share yield and the difference between supply and demand and found evidences about the existence of liquidity. Amihod and Mandelson came to this conclusion that liquidity is existed for changing the differences between supply and demand. They studied liquidity in an article titled "Pricing Capital Properties and the Difference in Supply and Demand". From their point of view, the difference between Supply and Demand is a good representation of liquidity evaluation. In an article titled "Corporative Governance and Liquidity", Chang (2010) theoretically studied the relationship between corporative governance and liquidity. In his studies, he showed that a high positive correlation is established between corporative governance and liquidity all the time. In a study, Hoi Wang et al. (2012) studied the relationship between the fame of financial intermediates and the determination of low-pricing of Initial Public Offering in China and found a positive relationship between financial intermediates and the yields of periods. During a study, Tolentino et al. (2010) investigated the Effects of Price Stabilization in IPOs on Long-run Liquidity and found out that there is a positive relationship between these two variables. Fitriya Fauzi (2012) studied the effect of global crisis on the price of Initial Public Offering in New Zealand's Stock Exchange and provided evidences about the short-term performances of the companies during global crisis. They showed that global financial crisis, influences the price of Initial Public Offering.

Little attention has been instead devoted to the link between secondary market liquidity and IPO underpricing. The only exception is the study by Booth and Chua (1996), who suggest that IPO underpricing aims to elicit the interest of a target number of potential investors. They assume that enlarging the pool of dispersed shareholders raises the valuation of the firm, by creating liquidity in the aftermarket, but requires attracting investors with higher information collection costs. The optimal price will weigh the liquidity benefit of added investor participation against its cost. Our article turns this argument on its head. Because different IPO shares feature different after-market liquidity, the IPO underpricing required to attract uninformed investors differs accordingly. The causality runs from aftermarket liquidity to IPO underpricing, contrary to Booth and Chua's logic. Also the predicted sign of the correlation between the two variables is opposite: higher underpricing should lead to greater liquidity according to Booth and Chua (1996) while greater liquidity calls for lower underpricing in our model.

In performed studies, researchers name a lot of characteristics of liquidity (Amihod \& Mandelson, 1986, 2000, 2008; Fang, 2009; Maug, 1998; Gambers et al., 2003; Edmans, 2009; Admati \& Poflider, 2009; Palmiter, 2002; Khana \& Sonti, 2004; Sab Rahmaniam \& Titman, 2002), that the most significant characteristic, is the low transaction charge of this kind of share. In this field, Amihod and Mandelson $(1986,2008)$ cited that all of the charges of share transfer which are paid by seller and purchaser is a part of liquidity's charge which is happened during the lack of complete liquidity. Furthermore, liquidity makes the prices of sell and purchase to get close to each other, so the seller and purchaser would try less to come into agreement for the transaction. (Amihod and Mandelson, 2006). Recognizing the significance of liquidity in developing partnership in financial markets, has pushed the world's Stock Exchanges forward in order to predict necessary solutions for removing the problem of liquidity in these markets (Booth \& Chua, 1996). Therefore The main purposes of the study is:

Research on the effect of after-market liquidity on (IPO)pricing in accepted corporations in Tehran Stock Exchange organization.

The below hypothesis has suggested to arriving to these purpose:

Hypothesis: There is a meaningful relationship between after-market liquidity and (IPO) price in Tehran Stock

Exchange organization.

\section{Method}

The relation between IPO pricing and after-market liquidity will be test by signaling model. Because the

After-market liquidity effect is quantifiable; the firms with high amount of after-market liquidity must have higher

IPO price. If Signaling theory after controlling all other elements effecting IPO price still has valid, we can find a positive relationship between after-market liquidity and IPO pricing. So, signaling theory predicts a strong and positive relationship between after-market liquidity and IPO pricing.

\subsection{Measurement of IPO Price}

To find out the role of after-market liquidity in IPO pricing, the study focus on the closing price on the day of Initial Public Offering. 


\subsection{Measurement of After-Market Liquidity}

In financial markets, liquidity is a degree in which the transactions in high volumes can be performed in a short period of time and have the lowest effects on price. An ideal index for liquidity should consist of these factors: volume, time and the price of transactions. Although some indexes such as transactions' volumes or turnover rates are easily accessible, but they are unable to reflect the transactional charges. Moreover, the differences between the sizes of shares are not included in these two indexes. Totally it can be said that there is no exact index for liquidity and the variable which are applied, are just for predicting and estimating the liquidity.

\section{Liquidity Criteria}

Liquidity criteria can be divided into 4 groups:

i. Criteria based on Transaction Charges;

ii. Criteria based on Transaction Volume;

iii. Criteria based on the Market;

iv. Criteria based on Equilibrium Price.

\section{Criteria Based on Transaction Volumes}

In this criterion, the liquid markets are determined through the transaction volume in comparison with price changes that these criteria are applied for calculating the dimensions of extents and the depth of liquidity. One of the liquidity criteria in this group is the Hui and Heubel Ratio. This ratio which is briefly shown as $\mathrm{L}_{\mathrm{hh}}$, is as follows:

$$
L R_{h h}=\left[P_{\max }-P_{\min } / P_{\min }\right] /\left[V / S^{*} P\right]
$$

$\mathrm{P}=$ the average closing price of shares over 5-days;

$\mathrm{V}=$ Turn over value;

$\mathrm{S}=$ Number of disseminated shares;

$\mathrm{P}=$ Average of last price in a day.

This model basically tries to measuring the market's extent to link the transaction volumes with their price effects. The less this ratio, is, the more the asset's liquidity will be and it mean that it is more extended.

\subsection{The Other Effective Variable on IPO Pricing}

Andrew Ellul and Marco Pagano (2006) to study on after-market liquidity and IPO underpricing also entered the underwriter reputation, firm size, high risk industries, IPO size and age that have effect on IPO pricing. Current research also for control other effective variables IPO pricing entered size, underwriter reputation, high risk industries, IPO size and age variables on its model. Forgoing variables are used in research in following manner:

\subsubsection{Firm Size}

There are various methods to assertion the firm size. For example, someone uses market values of equity of the firm. Sometimes the sell value of the firms is used for firm's size. Like Ellul and Pagano (2006) in this research, the total asset is utilizing as the firm size and because the firm size is very bigger than other variables, we use a logarithm of total asset to bring it near to the other variable size.

\subsubsection{Underwriter Reputation}

Underwriter reputation was defined under the title of the amount of underwriting credit of stocks and due to this fact that in Iran, the underwriting firms are under the direct supervision of Stock Exchange Organization and their regulations are all determined by this organization, all of them hold the same credit values.

\subsubsection{High Risk Industries}

Technological Industries are considered as hazardous industries and $0 \& 1$ nominal variables are used.

\subsubsection{IPO Size}

The size of Initial Public Offering refers to the volume of share dissemination on the day of Initial Public Offering and is calculated through the recorded information in Stock Exchange Market.

\subsubsection{Age}

Measured by logarithm of the number of years since incorporation like Ellul and Pagano (2006). 


\subsection{Sampling Procedure}

We use the financial statements information of the accepted corporation in Tehran stock exchange organization during 2006 to 2012 to test the relationship between IPO pricing and after-market liquidity. Therefore, this sample includes companies who have the following conditions:

1) The companies which performed the Initial Public Offering from September of 2006; 2) The companies whose transactions weren't paused more than three months during 2006 to 2012 in Stock Exchange; 3) The end of financial year of these companies was the end of March of each year and the firm shouldn't have altered its financial year during 2006 to 2012; 4) There should be an access to their financial statements and notes.

The data of more than 35 firms are used in the study for analysis.

\subsection{Methodology}

Because the study tries to find the relation between the after-market liquidity and IPO pricing variables, so

Methodology includes a type of correlation and uses a multivariable regression model to analyze the data. The regression model of the study is:

$$
\text { IPO Price }=b_{0}+b_{1} \text { Liquidity }+b_{2} \text { IPO Size }+b_{3} \text { Firm Size }+b_{4} \text { Age }+b_{5} \text { Reputation }+b_{6} \text { High risk }+\varepsilon
$$

\subsubsection{Testing of Hypotheses}

Test of hypothesis:

$\mathrm{H}_{0}: \beta=0$

$\mathrm{H}_{1}: \beta \neq 0$.

H1 hypothesis explain that there is a meaningful relationship between IPO pricing and after-market liquidity.

\section{Result}

In this research, the Ordinary Least Squares Regression (OLS) was used. For executing this test, a number of presuppositions should have presented to come to an accurate calculation of the performed Regression. Therefore, before performing the calculation, first we should test the presuppositions and then execute the Regression.

\subsection{Necessary Presuppositions for Executing OLS Regression}

By performing the test, the necessary presupposition related to zeroing the average of the remained components is done that according to the statistics of Hou test - which indicates the average of zero for the test components-, it is accepted and also for Variance Homology Test, we used White Heteroskedasticity Test. According to statistics of this test, which is above $5 \%$, the $\mathrm{H}_{0}$ hypothesis about variance homology is accepted. (Table 1 )

Table 1. Presupposition tests

\begin{tabular}{lll}
\hline Our Presupposition Test & T \& F Probability Statistics & Test Result \\
\hline Zero Average Test & $0 / 58$ & Approved \\
White Test & $0 / 72$ & Approved \\
\hline
\end{tabular}

Table 2 includes the descriptive statistics of the under-studying data for using in linear Regression. According to this fact that the statistical data and information were extracted from the data of 36 accepted firms in Tehran's Stock Exchange Market during 2006 to 2012, so each of the variables can have 36 observations. The observed calculated descriptive statistics consist of minimum, maximum, average and Standard Deviation.

Table 2. Descriptive statistics of research variables

\begin{tabular}{llllll}
\hline Statistic Variable & Number & Minimum & Maximum & Average & Standard deviation \\
\hline Liquidity of secondary market & 36 & 0 & 7616.599 & 439.19 & 1643.72 \\
Initial Public Offering Price & 36 & 1001 & 27147 & 4967.58 & 6052.58 \\
Firm Size & 36 & 11.82 & 19.82 & 15.88 & 1.79 \\
Firm Age & 36 & 1.36 & 4.82 & 3.04 & 0.78 \\
Initial Offering Size & 36 & 0.66 & 2230 & 223.75 & 414.02 \\
\hline
\end{tabular}




\subsection{Statistics and Data Analysis}

As it is inferred from Table 2, the difference between the minimum and maximum of the data, shows an appropriate range for using the variables. The results resulted from the indexes of central orientation and the dispersion of observed data indicated that the ratio of liquidity and Initial Public Offering Price have the highest Standard Deviation which reports the more dispersion and the less solidarity in the under-studying community. In order to prevent the samples from getting small, the observations weren't removed. The Initial Public Offering Price with the average of 439/36 and the Standard Deviation of 1643/72 have a high dispersion in various firms. The average of firm size is $15 / 88$ and the dispersion index of Standard Deviation is $1 / 79$, that the dispersion amount of this variable is low in various firms.

As it is obvious in Table 3, the F probability statistics of the total model is 0.001 . Therefore, it can be said that the total Regression is valid at the level of $99 \%$ confidence. Meanwhile it should be known that this reality was occurred in the chosen sample and probably in other samples, the intense of solidarity gets higher or lower.

Table 3. Test results

\begin{tabular}{|c|c|c|c|}
\hline \multicolumn{4}{|c|}{ Dependant Variable: Initial Offering Price } \\
\hline Independent \& Control Variables & Coefficient & $\mathrm{t}$ Variable & Probability of $t$ \\
\hline Liquidity & 0.626 & 4.685 & 0.000 \\
\hline Size of Initial Public Offering & -0.263 & 0.121 & 0.01 \\
\hline Firm Size & -0.241 & 0.157 & 0.27 \\
\hline Firm Age & -0.055 & 0.749 & 0.48 \\
\hline Underwriter reputation & 0 & 0 & 0.87 \\
\hline High Risk & 0.026 & 0.878 & 0.01 \\
\hline F Variable & 21.948 & Probability of F & 0.001 \\
\hline $\mathrm{R}^{2}$ Variable & 0.392 & Equilibrated $\mathrm{R}^{2}$ Coefficient & 0.374 \\
\hline
\end{tabular}

According to the resulted results, the $t$ variable with the amount of $4 / 685$ has a meaningful level of less than 0.05 which shows that the liquidity slope and the Initial Public Offering Price are both direct and meaningful. In other words, according to this fact that the calculated $t$ is positively higher than $1 / 96$, so the null hypothesis at the level of $95 \%$ is rejected and the opponent hypothesis which includes the positive effect is accepted. Therefore it can be accepted that in statistical community of the accepted firms in Tehran's Stock Exchange Market, there is a direct and positive relationship between the amount of liquidity and their Initial Public Offering price. Therefore, the liquidity of secondary market has a positive effect on the Initial Public Offering Price and also has a direct relationship with it. It means that if the liquidity of secondary market increases the Initial Public Offering Price increases too. This means that it seems the investors of the shares of newlyaccepted firms in Stock Exchange Market agree to pay higher amounts for gaining the shares of the firms which have higher transaction capability. The diagnosis coefficient of this model indicates that $0 / 392$ of changes in Initial Public Offering Price against one unit of Standard Deviation of changes in the amount of liquidity is detectable and it is a criterion for the goodness of Regression Equation. It shows that by an increase of one unit in the liquidity of secondary market, an increase of $0 / 40$ will occur in the Initial Public Offering Price.

Also according to variable $\mathrm{F}$, the Regression Model is meaningful and the liquidity variable of secondary market has a meaningful influence on the Initial Public Offering Price. In other words, the changes in Initial Public Offering Price are in line with the changes of secondary market's liquidity.

\subsection{The Effect of Control Variables}

This research shows a negative relationship between the size of Initial Public Offering and the price of it at the level of $95 \%$ confidence. Also according to the statistic of 0.27 between the firm size and the Initial Public Offering Price, the relationship between these two variables is rejected. The results of this test, rejects the relationship between the age of firms and underwriter reputation with the Initial Public Offering Price. Also the positive relationship between belonging to high risk industries and Initial Public Offering Price is approved.

\section{Discussion}

The study is about the effect of liquidity of secondary market on Initial Public Offering (IPO) Price. Analysis based on signaling model. Underwriter reputation variable, firm size variable, high risk industries variable, IPO size variable and age variable are the control variables. The results of this study explain that there is a positive 
and meaningful relationship between the liquidity of secondary market and Initial Public Offering Price. We can say that the more liquidity the share is, the higher will be the pricing. Also the contrary of this relationship is right. Because the more the share is liquidity, the risk of non-selling it get decreased. It means that the people get attracted by this share and its turnover gets increased in the market and pushes the market forward. As it was mentioned before, the high liquidity and the possibility of quick changes in share price, leads to attractiveness of the shares of newly-accepted firms in Stock Exchange Market for the investors. Other finding explain that in control variables that have a probability of effect on IPO price are the size of Initial Public Offering and belongingness to high risk industries. The results of last studies by Fang et al. (2009), Amihod and Mandelson (1986), Gambers et al. (2003), Edmans (2009), Khana and Sonti (2004) and Ellul and Pagano (2006) explain there is a meaningful and positive relationship between after-market liquidity and IPO price, and results of this study has conformity with them.

According to the above mentioned sayings, the following items can be suggested and presented to other experts:

\subsection{Suggestions}

According to this fact that it was diagnosed that the Initial Public Offering Price is totally in line and accordance to the liquidity of secondary market, it is suggested that when purchasing the shares of Initial Public Offering, users of Capital Market consider the liquidity of secondary market and don't take action to purchase those shares just because of their low Initial Public Offering Price.

\subsection{Agenda for Future Research}

1). It is suggested that the present research be performed separately according to various industries.

2). It is suggested that the relationship between the time of shares' Initial Public Offering (splendor or standstill period) and Initial Public Offering Price be studied.

3). It is suggested that the effect of different risks related to the Initial Public Offering Price be studied.

\section{References}

Admati, A., \& Pfleiderer, P. (2009). The wall street walk and shareholder activism: Exit as a form of voice. Review of Financial Studies, 22, 2645-2685. http://dx.doi.org/10.1093/rfs/hhp037

Amihud, Y., \& Mendelson, H. (1986). Asset pricing and the bid-ask spread. Journal of Financial Economics, 17 , 223-249. http://dx.doi.org/10.1016/0304-405X(86)90065-6

Baron, D. P. (1982). A model of the demand for investment banking advising and distribution services for new issues. Journal of Finance, 37, 955-1067. http://dx.doi.org/10.1111/j.1540-6261.1982.tb03591.x

Booth, J. R., \& Chua, L. (1996). Ownership dispersion, costly information, and IPO underpricing. Journal of Financial Economics, 41(2), 291-310. http://dx.doi.org/10.1016/0304-405X(95)00862-9

Busaba, W. Y., \& Chang, C. (2002). Bookbuilding vs. fixed price revisited: The effect of aftermarket trading. Journal of Corporate Finance, 16(3), 370-381 http://dx.doi.org/10.1016/j.jcorpfin.2009.11.001

Chang, Y. Y., Faff, R., \& Hwang, C. Y. (2010). Liquidity and stock returns in Japan: New evidence. Pacific-Basin Finance Journal, 18, 90-115. http://dx.doi.org/10.1016/j.pacfin.2009.09.001

Chemmanur, T. J. (1993). The pricing of initial public offerings: A dynamic model with information production. The Journal of Finance, 48, 285-305. http://dx.doi.org/10.1111/j.1540-6261.1993.tb04710.x

Edmans, A. (2009). Block holder trading, market efficiency, and managerial myopia. The Journal of Finance, 2481-2513. http://www.10.1111/j.1540-6261.2009.01508.x

Ellul, A., \& Pagano, M. (2006). IPO underpricing and after-market liquidity. Review of Financial Studies, 19(2), 381-421. http://dx.doi.org/10.1093/rfs/hhj018

Fang, V. W., Noe, T. H., \& Tice, S. (2009). Stock market liquidity and firm value. Journal of Financial Economics, 150-169. http://dx.doi.org/10.1016/j.jfineco.2008.08.007

Fauzi, F., Hewa-Wellalage, N., \& Locke, S. (2012). The impact of global financial crisis on short-term performance of IPO: The case study of New Zealand firms' IPO. Asian Journal of Finance \& Accounting, 4(2). http://dx.doi.org/10.5296/ajfa.v4i2.1829

Grinblatt, M., \& Hwang, C. Y. (1989). Signaling and the pricing of new issues. Journal of Finance, 44, 393-420. http://dx.doi.org/10.1111/j.1540-6261.1989.tb05063.x 
Hui, \& Huebel, B. (1984). Comparative liquidity advantages among major U.S. stock markets. DRI Financial Information Group Study Series.

Ibbotson, R. G. (1975). Price performance of common stock new issues. Journal of Financial Economics, 2, 235-272. http://dx.doi.org/10.1016/0304-405X(75)90015-X

Ibbotson, R., \& Jaff, J. (1975). Hot Issue Markets. Journal of Finance, 4, 1027-1042. Retrieved from http://www.jstor.org/stable/2326721

Khanjamali, H. (2006). Studying the relative efficiency of share pricing in selected industries, using the Data Covering Analysis Model. MA Thesis, Shahid Beheshti University, Faculty of Management \& Accounting.

Khanna, N., \& Sonti, R. (2004). Value creating stock manipulation: Feedback effect of stock prices on firm value. Journal of Financial Markets, 7, 237-270. http://dx.doi.org/10.1016/j.finmar.2003.11.004

Leland, H. E., \& Pyle, D. H. (1977). Information asymmetries, financial structure and financial intermediaries. Journal of Finance, 32, 125-135. http://dx.doi.org/10.2307/2326770

Loughran, T., Ritter, J., \& Rydquist, K. (1994). Initial public offerings: International insights. Pacific-Basin Finance Journal, 2, 165-199. http://dx.doi.org/10.1016/0927-538X(94)90016-7

Maug, E. (1998). Large shareholders as monitors: Is there a trade-off between liquidity and control? Journal of Finance, 53(1), 65-98. http://dx.doi.org/10.1111/0022-1082.35053

Moradi, Z. (2009). Studying the share' Initial Pricing Offering (IPO) in Tehran's Stock Exchange Market. Doctorate dissertation thesis, Islamic Azad University, Research \& Science Branch.

Muscarella, C. J., \& Vetsuypens, M. R. (1989). A simple test of Barron's model of IPO underpricing. Journal of Financial Economics, 24, 12-135. http://dx.doi.org/10.1016/0304-405X(89)90074-3

Palmiter, A. R. (2002). Mutual fund voting of portfolio shares: Why not disclose? Cardozo Law Review, 23(4), 1419-1491. Retrieved from http://hdl.handle.net/10339/26138

Rock, K. (1986). Why new issues are underpriced. Journal of Financial Economics, 15(1/2), 187-212. http://dx.doi.org/10.1016/0304-405X(86)90054-1

Roodgar, Z. (2011). Studying and comparing the liquidity capability of shares in Tehran's Stock Exchange Market in different levels. MA Thesis, Islamic Azad University, Research \& Science Branch.

Takik, N. E. (2010). Diagnosing the financial \& non-financial factors on the short-term performance of Initial Offering Period of shares in Tehran's Stock Exchange Market'. MA Thesis, Islamic Azad University, Research \& Science Branch.

Talebnia, G. (1993). The problems of shares' pricing methods of the firms included transferring in Tehran's Stock Exchange Market. Doctorate dissertation thesis, Tehran University.

Tolentino, R., \& Gledson de Carvalho, A. (2010). Effects of price stabilization in IPOs on long-run liquidity. Journal of Revista Brasileira de Finanças, 8(3), 307-328. Retrieved from http://virtualbib.fgv.br/ojs/index.php/rbfin/article/view/2559

Welsch, G. A., \& Zlatkovich, C. T. (1989). Intermediate Accounting (8th ed., p. 904). Irwin.

Yavari, S. (1998). Studying the effective factors on calculation and the amount of Beta systematic risk'. MA Thesis, Islamic Azad University, Central Branch.

Zareh, E. M. (2002). Studying the effective factors on the liquidity capability of shares in Tehran's Stock Exchange Market. MA Thesis in the field of Management; Imam Sadegh University.

\section{Copyrights}

Copyright for this article is retained by the author(s), with first publication rights granted to the journal.

This is an open-access article distributed under the terms and conditions of the Creative Commons Attribution license (http://creativecommons.org/licenses/by/3.0/). 